Mеталлофиз. новейшие технол. / Metallofiz. Noveishie Tekhnol. (C) 2015 ИМФ (Институт металлофизики 2015 , т. 37 , № 4 , сс. 539-554

Оттиски доступны непосредственно от издателя

им. Г. В. Курдюмова НАН Украины)

Фотокопирование разрешено только

Напечатано в Украине.

в соответствии с лицензией

PACSnumbers: 06.60.Vz, 68.37.Lp, 81.20.Vj, 81.40.Pq, 81.65.Kn, 81.65.Rv, 82.45.Bb

\title{
Microstructure and Salt Fog Corrosion Behaviour of AA2219 Friction Stir Welded Aluminium Alloy
}

\author{
G. Srinivasa Rao, V. V. Subba Rao*, and S. R. Koteswara Rao** \\ Department of Mechanical Engineering, ASIST, \\ Paritala, India \\ "Department of Mechanical Engineering, JNTUK, \\ Kakinada, India \\ "Department of Mechanical Engineering, Tagore Engineering College, \\ Chennai, India
}

\begin{abstract}
Aluminium alloy 2219 is a favourite age hardenable alloy considered for fabrication of earth storable and cryogenic propellant tanks of launch vehicles. In the current study, $8.1 \mathrm{~mm}$ thick AA2219-T87 aluminium alloy plates are joined using friction stir welding. Friction stir welding produces three different microstructural zones, and these zones exhibit different microstructural characteristics. Therefore, it is expected that the various zones will exhibit different corrosion susceptibility. The corrosion behaviour of the base material and friction stir welded joints is investigated using salt fog test (ASTM B117) at different $\mathrm{pH}$ value and spraying times. Optical microscopy and transmission electron microscopy are used to observe the corrosion attack at various zones of the weld. As observed, the welds exhibit excellent corrosion resistance in basic and neutral solution than in acidic solution. As found, the corrosion rate decreases with increase in time of exposure at all $\mathrm{pH}$ values. As observed, the corrosion rate is predominant in acidic solution for first $24 \mathrm{hrs}$ of spraying time. As found, the corrosion attack is greater in the base material than weld metal at all $\mathrm{pH}$ value and spraying times. Within the weld, the heat-affected zone (HAZ) is found to be more susceptible to corrosion compared to the weld nugget and thermomechanically affected regions. The results obtained from the transmission electron microscopy confirm that the increased rate of corrosion of HAZ in acidic solution is due to the precipitation of second phase particles $\left(\mathrm{CuAl}_{2}\right)$ at the grain boundaries causes depletion of copper near the grain boundaries, making these regions anodic to the grain centre.
\end{abstract}

Алюмінійовий стоп 2219 є найкращим вибором серед дисперсійнотвердних стопів, які розглядаються для виготовлення баків для ракетного палива тривалого зберігання в наземних умовах і баків для кріогенного ракетного палива мобільних пускових установок. У даній роботі платівки 
алюмінійового стопу АА2219-Т87 товщиною у 8,1 мм були з'єднані способом зварювання тертям з перемішуванням. Зварювання тертям з перемішуванням створює три різних мікроструктурних зони, i ці зони демонструють різні мікроструктурні характеристики. Тому можна очікувати, що різні зони будуть демонструвати різну сприйнятливість до корозії. Корозійні властивості основного металу та зварних швів, одержаних зварюванням тертям 3 перемішуванням, досліджувалися з використанням випробування в сольовому тумані (ASTM B117) за різних значень $\mathrm{pH}$ та часів розпорошення. Оптична мікроскопія та просвітна електронна мікроскопія використовувалися для спостереження корозійного руйнування в різних зонах зварного шва. Було встановлено, що зварні шви демонструють відмінну корозійну стійкість у лужних та нейтральних розчинах, але не в кислих розчинах. Встановлено, що швидкість корозії зменшується з ростом часу витримки при всіх значеннях $\mathrm{pH}$. Швидкість корозії була максимальною в кислому розчині впродовж перших 24 годин тривалости витримки. Корозійне руйнування більше в основному металі, ніж у матеріялі зварного шва за всіх $\mathrm{pH}$ і тривалостей розпорошення. Всередині зварного шва зона термічного впливу (ЗТВ) виявилася більш сприйнятливою до корозії порівняно з ядром зварної точки та термомеханічно пошкодженими районами. Результати, одержані за допомогою просвітної електронної мікроскопії, підтвердили, що збільшена швидкість корозії ЗТВ у кислотному розчині обумовлена виділенням частинок другої фази $\left(\mathrm{CuAl}_{2}\right)$ біля меж зерен, що призводить до збіднення міді поблизу меж зерен, роблячи ці райони анодними відносно центру зерна.

Алюминиевый сплав 2219 является наилучшим выбором среди дисперсионно-твердеющих сплавов, рассматриваемых для изготовления баков для ракетного топлива длительного хранения в наземных условиях и баков для криогенного ракетного топлива мобильных пусковых установок. В данной работе пластины алюминиевого сплава АА2219-Т87 толщиной 8,1 мм были соединены путём сварки трением с перемешиванием. Сварка трением с перемешиванием образует три различные микроструктурные зоны, и эти зоны демонстрируют разные микроструктурные характеристики. Поэтому можно ожидать, что разные зоны будут демонстрировать разную восприимчивость к коррозии. Коррозионные свойства основного металла и сварных швов, полученных сваркой трением с перемешиванием, исследовались с использованием испытания в солевом тумане (ASTM В117) при различных значениях $\mathrm{pH}$ и времени распыления. Оптическая микроскопия и просвечивающая электронная микроскопия использовались для наблюдения коррозионного разрушения в различных зонах сварного шва. Было установлено, что сварные швы демонстрируют отличную коррозионную стойкость в щелочных и нейтральных растворах, но не в кислых растворах. Установлено, что скорость коррозии уменьшается с увеличением времени выдержки при всех значениях $\mathrm{pH}$. Скорость коррозии была максимальной в кислом растворе в течение первых 24 часов времени выдержки. Коррозионное разрушение больше в основном металле, чем в материале сварного шва при всех $\mathrm{pH}$ и временах распыления. Внутри сварного шва зона термического влияния (ЗТВ) оказалась более восприимчивой к коррозии по сравнению с ядром сварной точки и термомеханически повреждёнными районами. Результаты, полученные с по- 
мощью просвечивающей электронной микроскопии, подтвердили, что возросшая скорость коррозии ЗТВ в кислотном растворе обусловлена выделением частиц второй фазы $\left(\mathrm{CuAl}_{2}\right)$ у границ зёрен, что приводит к обеднению меди вблизи границ зёрен, делая эти районы анодными относительно центра зерна.

Key words: AA2219-T87 aluminium alloy, corrosion, salt spray (fog) test, $\mathrm{pH}$, spraying time, optical microscopy, transmission electron microscopy.

(Received December 24, 2014)

\section{INTRODUCTION}

AA2219 is an age hardenable $\mathrm{Al}-\mathrm{Cu}$ alloy widely used in aerospace and defence applications due to its excellent weldability and high strength to weight ratio. However, its only disadvantage is its poor resistance to corrosion owning to the galvanic coupling between noble $\mathrm{CuAl}_{2}$ precipitates and the matrix. If there could be some means by which $\mathrm{CuAl}_{2}$ could be taken into solution, the corrosion resistance of the alloy can be improved, though this might lower the mechanical properties to some extent. Friction stir welding (FSW) is a solid state welding process in which melting does not occur but temperatures are sufficiently high enough to cause dissolution and coarsening of strengthening precipitates in heat treatable aluminium alloys [1].

Friction stir welding produces three different microstructural zones: the weld nugget, the thermomechanically affected zone (TMAZ) and heat affected zone (HAZ): the weld nugget (WN) where the material experiences severe stirring and heating resulted in fine equiaxed grains, the thermomechanically affected zone, which is subjected to both deformation and heating but that temperature is not sufficient to cause recrystallization, and the heat affected zone, where the material experiences only heat with no mechanical deformation. These zones exhibit different microstructural characteristics. Therefore, it is expected that the various zones will exhibit different corrosion susceptibility. There have been a number of reports [2-20] highlighting the microstructural changes due to the plastic deformation and frictional heat associated with FSW. Dissolution and coarsening of strengthening precipitates $[2-5,11,16-20]$ as well as the formation of wide precipitate-free zones $[3,5,11,18]$ have been found in the weld region. Mechanical failure of the welds can take place in the WN, HAZ, or TMAZ regions depending on the amount of heat input, which is governed by process parameters such as rotation and travel speeds [1214]. The dependence of weld microstructure on processing parameters has been also observed [15-17]. Although no solid-liquid phase transformation occurs during FSW, relatively high temperatures, up to $475^{\circ} \mathrm{C}$ for $\mathrm{AA} 7075$ aluminium alloy, are generated by friction between 
the tool and the work piece [21, 22]. This produces modified microstructures that may be more susceptible to corrosion than the parent alloy.

A number of authors [23-35] have investigated the corrosion behaviour of FSW in $2 \mathrm{xxx}, 7 \mathrm{xxx}$, and $5 \mathrm{xxx}$ series aluminium alloys. Corrosion attack in the WN has been found for AA2024-T3 [32], AA2024T351, AA5456-H116, and AA7010-T7651 [35]. For AA7050-T7651 [25], attack was found at the interface between the WN and the partially recrystallized zone (TMAZ). A number of studies have shown attack to be predominantly in the HAZ, for example in AA7075-T651 [26], AA7075-T6 [27], AA2024-T351 [24, 34, 35] and AA7010-T7651 [23]. It has also been found that the weld region can show no worse corrosion susceptibility than the base metal (in AA2024-T3 and AA2195 welds [30]), and even in some cases, improved corrosion resistance compared with the base material (AA5454 [29], AA5083 [31], AA2024-T3 [33], AA2195, and AA2219 [28]). While many studies have been carried out to investigate the effect of FSW on the microstructure and corrosion properties of aluminium alloys, there are very few studies on the effect of varying $\mathrm{pH}$ value of the salt solution and spraying times used. Moreover, there has not been any systematic study reporting the relationship between exposure times and corrosion behaviour. Thus, the aim of this work is to investigate how corrosion behaviour changes with $\mathrm{pH}$ value, microstructure and time of exposure.

\section{EXPERIMENTAL PROCEDURE}

Base material used in this study is aluminium alloy AA2219-T87 plates of $8.1 \mathrm{~mm}$ in thickness. Chemical composition of the material is given in Table 1. FSW trials were carried out on a Friction Stir Welder at DMRL, Hyderabad. A pair of work pieces of dimension $300 \times 110 \times 8.1$ $\mathrm{mm}^{3}$ are abutted and clamped rigidly on the backing plate. The friction stir welding tool was machined from M2 tool steel. After conducting several trials with different tool pin profiles, it was found that tapered threaded pin offers ease of welding and sound joints. The geometry of the tool and the process parameters used in this study are presented in Table 2. Transverse sections were cut from welded plates for corrosion studies with a size of $50 \times 20 \times 8.1 \mathrm{~mm}^{3}$ and prepared for metallographic examination following standard metallographic practices. The polished specimens were etched with Keller's $\left(5 \% \mathrm{HNo}_{3}, 2 \% \mathrm{HCl}, 1 \% \mathrm{HF}\right)$

TABLE 1. Chemical composition of AA2219-T87 in wt. $\%$.

\begin{tabular}{c|c|c|c|c|c|c}
\hline $\mathrm{Cu}$ & $\mathrm{Mn}$ & $\mathrm{Zr}$ & $\mathrm{Ti}$ & $\mathrm{Fe}$ & $\mathrm{Si}$ & Rest \\
\hline 6.7 & 0.30 & 0.07 & 0.06 & 0.14 & 0.10 & $\mathrm{Al}$ \\
\hline
\end{tabular}


TABLE 2. The tool geometry and process parameters used for friction stir welding.

\begin{tabular}{l|l}
\hline \multicolumn{1}{c|}{ Nomenclature } & \multicolumn{1}{c}{ Weld parameters } \\
\hline & $\begin{array}{l}\text { Taper threaded pin (left hand metric threads with } \\
\text { Tool geometry }\end{array}$ \\
& $\begin{array}{l}\text { and } 4 \mathrm{~mm} \text { (tip end); Pin length: } 6.8 \mathrm{~mm} \text {; shoulder } \\
\text { diameter: } 20 \mathrm{~mm}\end{array}$ \\
Tool rotational Speed & $\begin{array}{l}800 \mathrm{rpm} \\
\text { Welding speed }\end{array}$ \\
Tool tilt & $1.5^{\circ}$ \\
\hline
\end{tabular}

reagent to reveal the microstructure. The macro- and microstructures of different zones were observed using a Leica DMLM light microscope. Images were taken from different locations of the weld joint before corrosion.

Transmission electron microscopy (TEM) is employed to ascertain the shape, size, distribution, and the status of the precipitates of the base material and different zones of the weld. There are several stages involved in the preparation of samples for TEM. Sections were initially cut from different zones of the etched sample of the weldment using electric discharge machining (EDM) as shown in Fig. 1, so that the samples consist of fully weld nugget, thermomechanically affected zone, and heat affected zone. These samples were polished to $\cong 100 \mu \mathrm{m}$ thickness by attaching the sample on TEM wax. Both processes mentioned above were carried out in flowing coolant and water to avoid raise in temperature.

The disc punch is used to extract $3 \mathrm{~mm}$ diameter specimens from

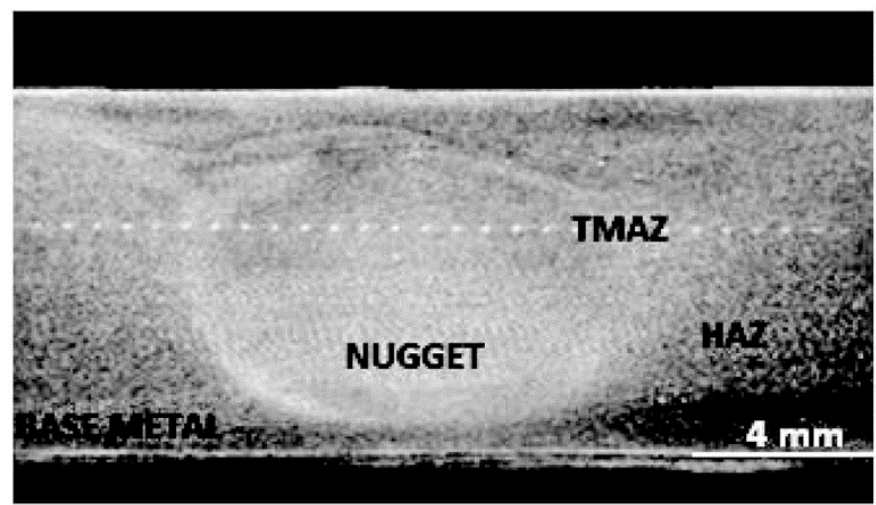

Fig. 1. Macrostructure of $8.1 \mathrm{~mm}$ thick friction stir welded AA 2219-T87 joint. 
thin sections and further ground mechanically using disc grinder. Finally, ion milling is used to create a dimple on each side of the disc, which is enlarged and forms a hole surrounded by a thin electrontransmissive region. Electron microscope JEM-2100 with EDX capabilities is used to study the samples. The samples were loaded into the machine on a double tilting, low background, beryllium holder.

The salt spray (fog) test was conducted on the welds as well as on the base materials according to ASTM B 117-07 [36] standards. This apparatus consists of a fog chamber, a salt solution reservoir, a supply of suitably conditioned compressed air, two atomizing nozzles, and specimen supports. The salt solution is prepared by dissolving $5 \pm 1$ parts by mass of sodium chloride in 95 parts of water and keeping $\mathrm{pH}$ at different levels as 2,7 , and 11 . The salt fog is produced in the chamber by simultaneously spraying salt solution from reservoir and compressed air from the air compressor. As the spray is continuous, the samples are continuously wet and therefore uniformly subjected to corrosion. Specimens are hanged $15^{\circ}$ to $35^{\circ}$ from vertical in the fog chamber in such a way that salt solution from one specimen should not drip on any other specimen. The weight loss of the material is measured after a period of time, and corrosion rate (in mils per year-mpy) is calculated using formula. Specimens, which have shown higher corrosion rate, are considered as less resistant to general corrosion. The specimens are taken out for every $24 \mathrm{hrs}$. The corroded layer on the surface of the specimen is carefully removed using ultrasonic cleaner, chemical reagents \& distilled water. The corrosion rate is calculated by weight loss measurement. Weight loss is measured by considering difference in initial weight $\left(W_{\mathrm{i}}\right)$ and final weight $\left(W_{\mathrm{f}}\right)$ of the specimens. The corrosion rate is calculated using the following equation:

$$
\text { Corrosion rate }(\mathrm{mm} / \text { year })=8.76 \cdot 10^{4} w /(A D T),
$$

where $w$ is the weight loss in grams, $A$-the surface area of the specimen in $\mathrm{cm}^{2}, D$-the density of the material in $\mathrm{gram} / \mathrm{cm}^{3}, T$ is the time of exposure or spraying time in hours. The corroded samples are polished once again by disc polishing for scratch free surfaces and the surface is observed at $500 \mathrm{X}$ magnification.

\section{RESULTS AND DISCUSSION}

\subsection{Macrostructure}

Figure 1 shows macrostructure of $8.1 \mathrm{~mm}$ thick friction stir welded joint without voids and cracks. The weld has an elliptical cross section with a zone around the weld nugget that has undergone severe plastic deformation. 
It is generally known that the fusion welding of aluminium alloys, accompanied by defects such as porosity, slag inclusions and solidification cracks deteriorate the weld quality and joint properties. Usually, friction stir welded joints are free from solidification-related defects, since no melting takes place during welding and the metals are joined together due to the heat generated by friction and the flow of metal by the stirring action. However, FSW joints are prone to other defects such as pinhole, tunnel defect, piping defect, kissing bond, zigzag line and cracks due to improper flow of metal and insufficient consolidation of metal in the FSW weld nugget region [39]. As can be seen from Fig. 1, no obvious welding defect was found in the joint, indicating that a sound weld is produced.

Based on the microstructural characterization of grains and precipitates, three distinct zones have been identified: stir zone (weld nugget), thermomechanically affected zone, and heat affected zone. A typical macrographs showing various microstructural zones of the elliptical cross section with a zone around the weld nugget, which seems to be a common feature in aluminium alloy friction stir welds has been reported by various investigators $[4,11]$.

\subsection{Microstructures}

Figures 2 and 3 show the results of optical microscopy (OM) and transmission electron microscopy respectively. The microstructure of the base material consists of elongated grains in the rolling direction and large second-phase particles are distributed randomly in the base material (see Fig. 2, a). The measured grain size for the base material in the rolling direction is $100 \mu \mathrm{m}$. The transmission electron micrograph of the base material is shown in Fig. 3, $a$. For the alloy AA2219, copper is a principal alloying element and the primary strengthening precipitates are the metastable $\theta^{1}$ and $\theta^{11}$ phases [37]. In the current study, the measured size of these precipitates ranged from 25 to $100 \mathrm{~nm}$.

The optical micrograph of the weld nugget is shown in Fig. 2, $b$. It has been observed that the initial elongated grains of the base material are mechanically converted into a new recrystallized equiaxed fine grain structure, which is formed as a result of severe plastic deformation and high temperatures caused by the rotational speed of the tool involved in the stirring process. The average value of these recrystallized fine equiaxial grains is in the range of $2-4 \mu \mathrm{m}$. The value obtained is in good agreement with Ref. [38]. The TEM image of the weld nugget (see Fig. 3, $b$ ) is marked by the absence of well-aligned discshaped precipitates. It indicates that the temperature experienced in the weld nugget during FSW process is about $500^{\circ} \mathrm{C}$, which is above the solution temperature and below the melting temperature of the alloy $[39,40]$. At this temperature, these precipitates have gone into solu- 
tion during the welding process. This result is in good agreement with Ref. [38].

Thermomechanical affected zone is the region surrounding the weld nugget on either side, which experiences both temperature and deformation during friction stir welding as shown in (Fig. 2, c). It is found that the elongated grains in the base material are deformed in an upward flowing pattern on either side of the weld nugget. Though this region underwent plastic deformation, recrystallization did not occur due to insufficient deformation strain.

Figure 3,c shows the micrograph of the TMAZ. It can be seen that the TEM image of the TMAZ is similar to that of the weld nugget with the morphology of the precipitates. It indicates that the dissolution of the metastable phases is not as extensive as that in weld nugget due to lower temperatures $\left(460^{\circ}\right)$ obtained during welding process [38].

Heat affected zone is shown in Fig. 2, $d$. Beyond the TMAZ there is a heat-affected zone. This zone experiences to heat about $250^{\circ} \mathrm{C}$ exerted a significant effect on the precipitate structure. It is found that the $\mathrm{HAZ}$ retains the same grain structure as the base material.
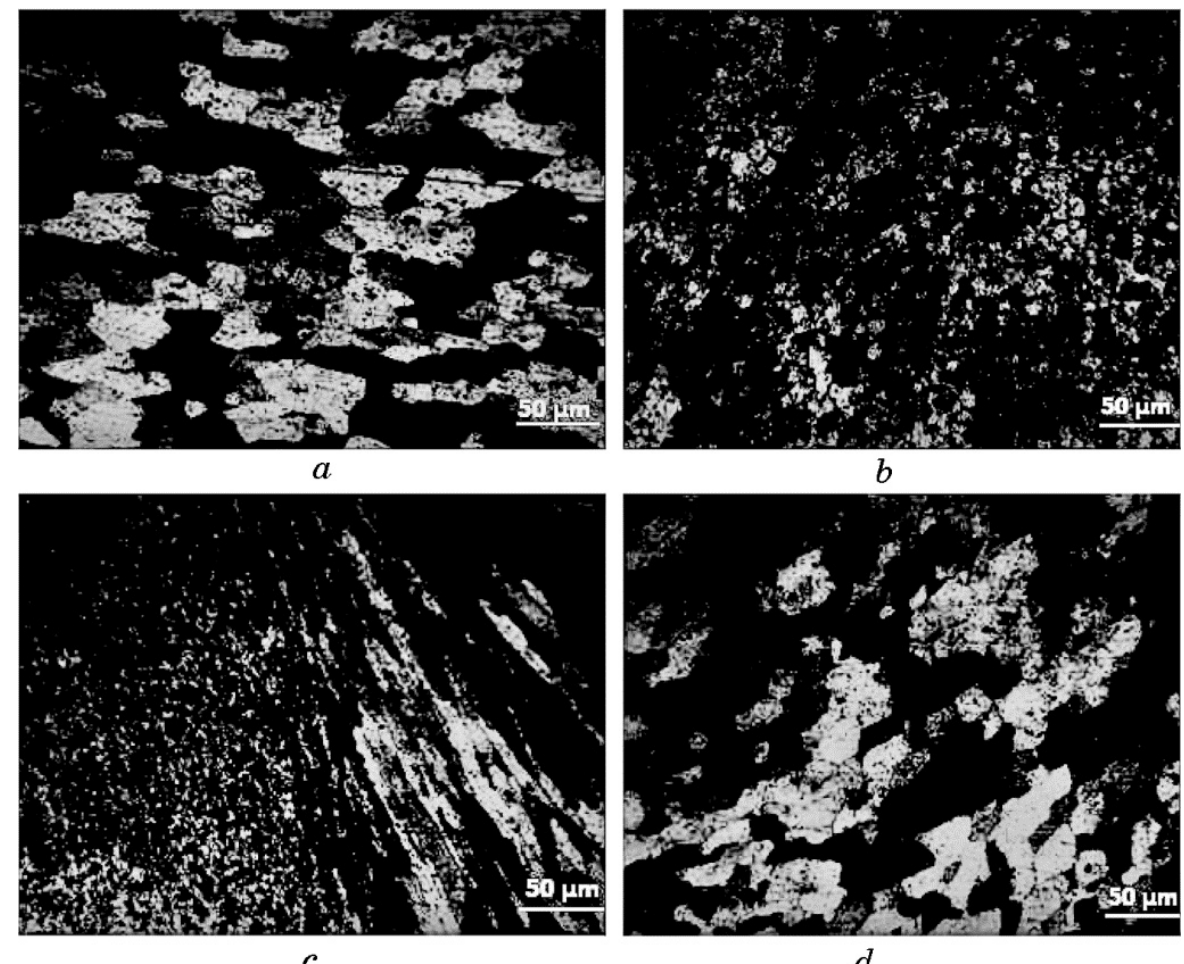

Fig. 2. Optical micrographs of friction stir welded AA2219-T87 (a); base material (b); weld nugget (c); TMAZ $(d)$ HAZ. 
Figure 3 shows the TEM image of HAZ. It can be seen that the structural form of the precipitates in $\mathrm{HAZ}$ is the same as that of the base material. If $\mathrm{Al}-\mathrm{Cu}$ alloys are aged above $190^{\circ} \mathrm{C}$, the equilibrium $\mathrm{CuAl}_{2}$ intermetallic compound $(\theta)$ is formed and the alloy is severely overaged and weaker than base material [38]. With temperatures in the range of 150 to $250^{\circ} \mathrm{C}$ in the $\mathrm{HAZ}$ region of the welded plates [38], the coarsening of precipitates in this region in turn forms precipitated free zones. These zones are obviously regions of weakness.

\subsection{Corrosion Properties}

The corrosion rates of base material and friction stir welds for $\mathrm{pH}$ val-
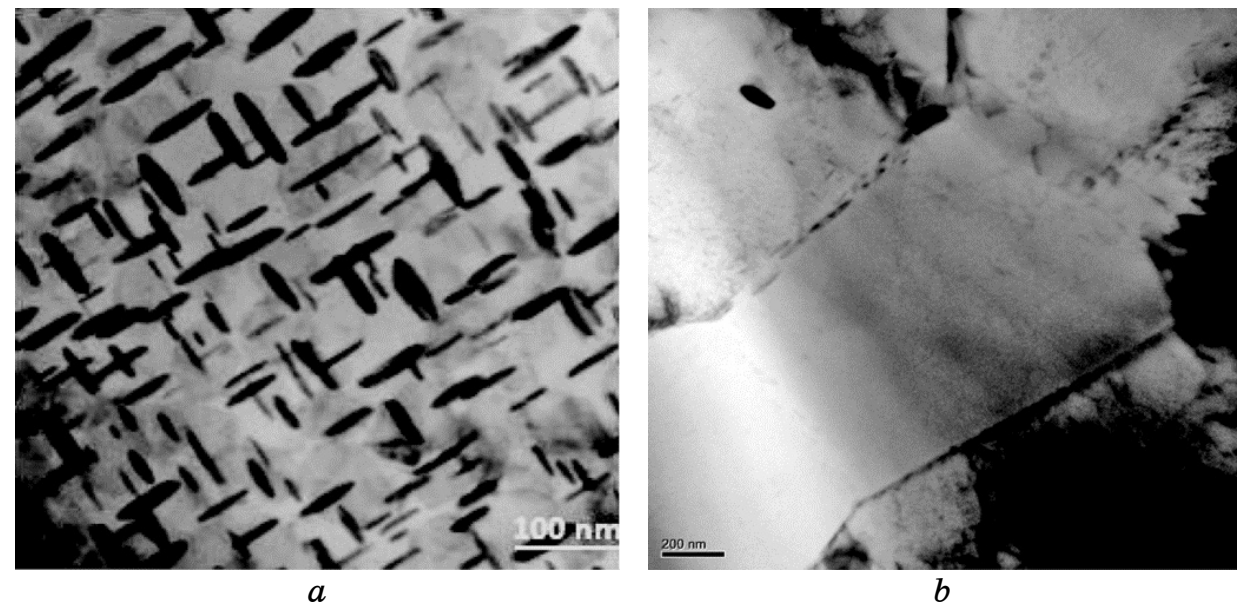

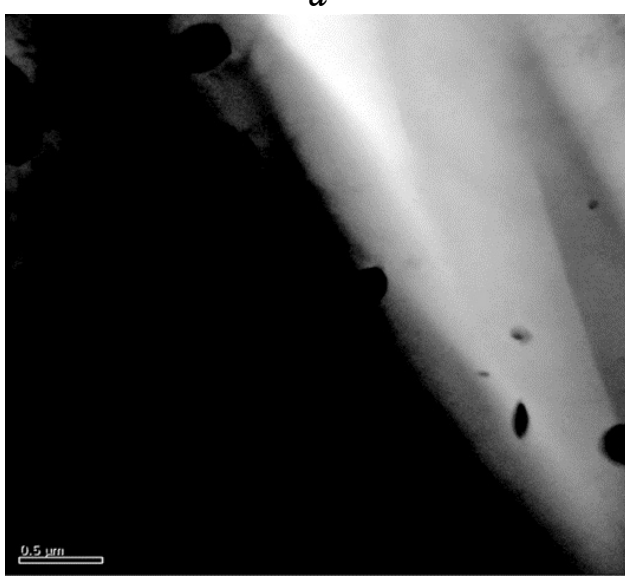

$c$

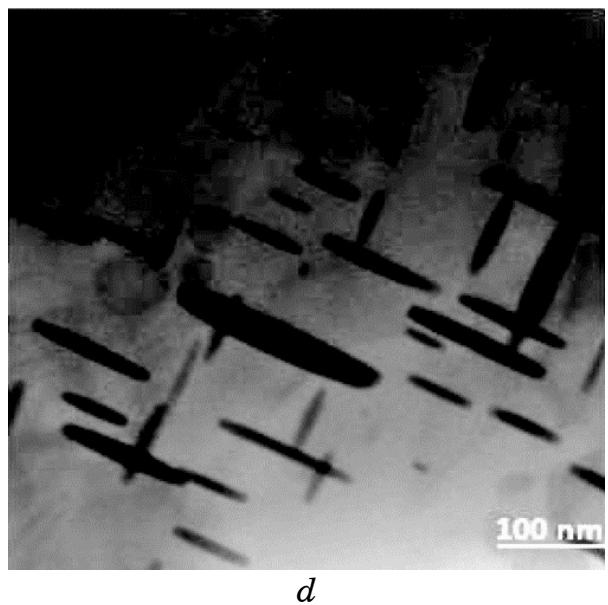

Fig. 3. Transmission electron micrographs of friction stir welded AA2219T87 (a); base material (b); weld nugget (c); TMAZ (d) HAZ. 
ue at different times of exposure $(28,48$ and $72 \mathrm{hrs})$ are presented in Table 3. It is observed that the corrosion rate of the weld decreases with increase in time of exposure.

The same trend found to occur for $\mathrm{pH}$ value of 7 (Table 4) and $\mathrm{pH}$ value of 11 (Table 5). It is found that the corrosion resistance of the weld is better than that of the base material. It has been found that the corrosion resistance of the weld increases with an increase in $\mathrm{pH}$ value.

TABLE 3. Corrosion rates for $\mathrm{pH}$ value of 2 at various times of exposure.

\begin{tabular}{|c|c|c|c|c|c|c|c|c|}
\hline \multirow{2}{*}{ o. } & \multirow{2}{*}{ Material } & \multirow{2}{*}{ pe } & \multirow{2}{*}{\begin{tabular}{|c|} 
Weight \\
before \\
corrosion, $\mathrm{g}$
\end{tabular}} & \multicolumn{3}{|c|}{ Weight after corrosion, $\mathrm{g}$} & \multirow{2}{*}{$\begin{array}{l}\text { Weight } \\
\text { loss, g }\end{array}$} & \multirow{2}{*}{$\begin{array}{c}\text { Corrosion } \\
\text { rate, } \\
\text { mm/year }\end{array}$} \\
\hline & & & & $24 \mathrm{~h}$ & 48 & $72 \mathrm{~h}$ & & \\
\hline 1 & & $\begin{array}{l}\mathrm{B} \\
\mathrm{B}\end{array}$ & & & & & & \\
\hline 2 & $v$ & $\begin{array}{l}\text { W1 } \\
\text { W2 } \\
\text { W3 }\end{array}$ & $\begin{array}{l}16.8228 \\
16.5021 \\
15.3405\end{array}$ & & 29 & 15.3319 & & \\
\hline
\end{tabular}

TABLE 4. Corrosion rates for $\mathrm{pH}$ value of 7 at various times of exposure.

\begin{tabular}{|c|c|c|c|c|c|c|c|c|}
\hline \multirow{2}{*}{ No. } & \multirow{2}{*}{ Material } & \multirow{2}{*}{ Type } & \multirow{2}{*}{$\begin{array}{c}\text { Weight } \\
\text { before } \\
\text { corrosion, g }\end{array}$} & \multicolumn{3}{|c|}{ Weight after corrosion, $\mathrm{g}$} & \multirow{2}{*}{$\begin{array}{l}\text { Weight } \\
\text { loss, g }\end{array}$} & \multirow{2}{*}{$\begin{array}{l}\text { Corrosion } \\
\text { rate, } \\
\text { mm/year }\end{array}$} \\
\hline & & & & $24 \mathrm{~h}$ & $48 \mathrm{~h}$ & $72 \mathrm{~h}$ & & \\
\hline 1 & Base & $\begin{array}{l}\text { B1 } \\
\text { B2 } \\
\text { B3 }\end{array}$ & $\begin{array}{l}16.8423 \\
16.2003 \\
15.3195\end{array}$ & 16.8374 & 16.1856 & 15.3108 & $\begin{array}{l}0.0049 \\
0.0089 \\
0.0087\end{array}$ & $\begin{array}{l}6.4334 \\
5.8426 \\
3.8075\end{array}$ \\
\hline 2 & Weld & $\begin{array}{l}\text { W1 } \\
\text { W2 } \\
\text { W3 }\end{array}$ & $\begin{array}{l}14.3510 \\
16.0670 \\
14.2264\end{array}$ & & 16.0649 & 14.2245 & $\begin{array}{l}0.0022 \\
0.0021 \\
0.0019\end{array}$ & $\begin{array}{l}2.8884 \\
1.3785 \\
0.8315\end{array}$ \\
\hline
\end{tabular}

TABLE 5. Corrosion rates for $\mathrm{pH}$ value of 11 at various times of exposure.

\begin{tabular}{|c|c|c|c|c|c|c|c|c|}
\hline \multirow{2}{*}{ No. } & \multirow{2}{*}{ Material } & \multirow[b]{2}{*}{ Type } & \multirow{2}{*}{\begin{tabular}{|c|} 
Weight \\
before \\
corrosion, $\mathrm{g}$
\end{tabular}} & \multicolumn{3}{|c|}{ Weight after corrosion, $\mathrm{g}$} & \multirow{2}{*}{$\begin{array}{l}\text { Weight } \\
\text { loss, g }\end{array}$} & \multirow{2}{*}{$\begin{array}{l}\text { Corrosion } \\
\text { rate, } \\
\text { mm/year }\end{array}$} \\
\hline & & & & $24 \mathrm{~h}$ & $48 \mathrm{~h}$ & $72 \mathrm{~h}$ & & \\
\hline 1 & Base & $\begin{array}{l}\text { B1 } \\
\text { B2 } \\
\text { B3 }\end{array}$ & $\begin{array}{l}14.3510 \\
16.0670 \\
14.2264\end{array}$ & \multicolumn{3}{|c|}{$\begin{array}{r}14.2188 \\
16.0549\end{array}$} & $\begin{array}{l}0.0002 \\
0.0005 \\
0.0008\end{array}$ & $\begin{array}{l}0.2625 \\
0.3282 \\
0.3501\end{array}$ \\
\hline 2 & Weld & $\begin{array}{l}\text { W1 } \\
\text { W2 } \\
\text { W3 }\end{array}$ & $\begin{array}{l}15.8173 \\
14.4262 \\
15.4687\end{array}$ & \multicolumn{2}{|c|}{15.8126} & 15.4679 & $\begin{array}{l}0.0004 \\
0.0007 \\
0.0008\end{array}$ & $\begin{array}{l}0.5251 \\
0.4590 \\
0.3501\end{array}$ \\
\hline
\end{tabular}



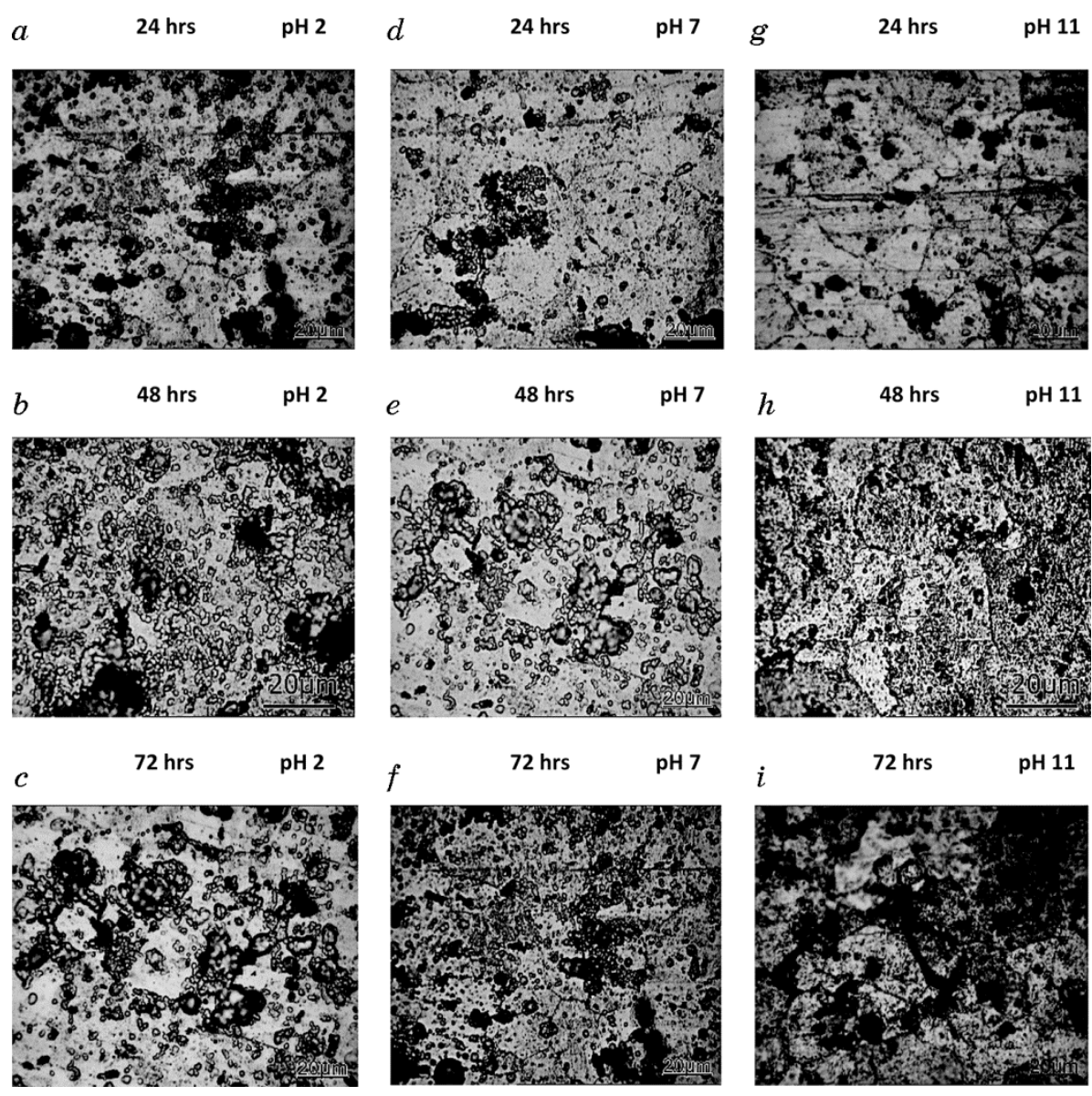

Fig. 4. Optical micrographs of the base material at $\mathrm{pH} 2(a, b, c), \mathrm{pH} 7(d, e, f)$ and $\mathrm{pH} 11(g, h, i)$ and corresponding spraying time (24, 48 and $72 \mathrm{hrs})$.

Figure 4 shows microstructures of the base material for all $\mathrm{pH}$ values at corresponding times of exposure. It was identified that corrosion attack on the base material is the highest for $\mathrm{pH} 2$ at the spraying time of $24 \mathrm{~h}$. Corrosion attack on base material seemed to be much less for $\mathrm{pH}$ value of 11. Aluminium alloy 2219 has two types of the second phase particles, viz., intermetallic phases formed during casting and those formed during aging. Both these second phase particles influence corrosion.

Corrosion attack on weld nugget is evident (Fig. 5) and no significant difference in the attack is seen based on $\mathrm{pH}$ value and spraying time. TMAZ of the weld region is also attacked by the corrosion (Fig. 6) and there remains no difference in the attack with reference to $\mathrm{pH}$ value of the solution and time of exposure. 

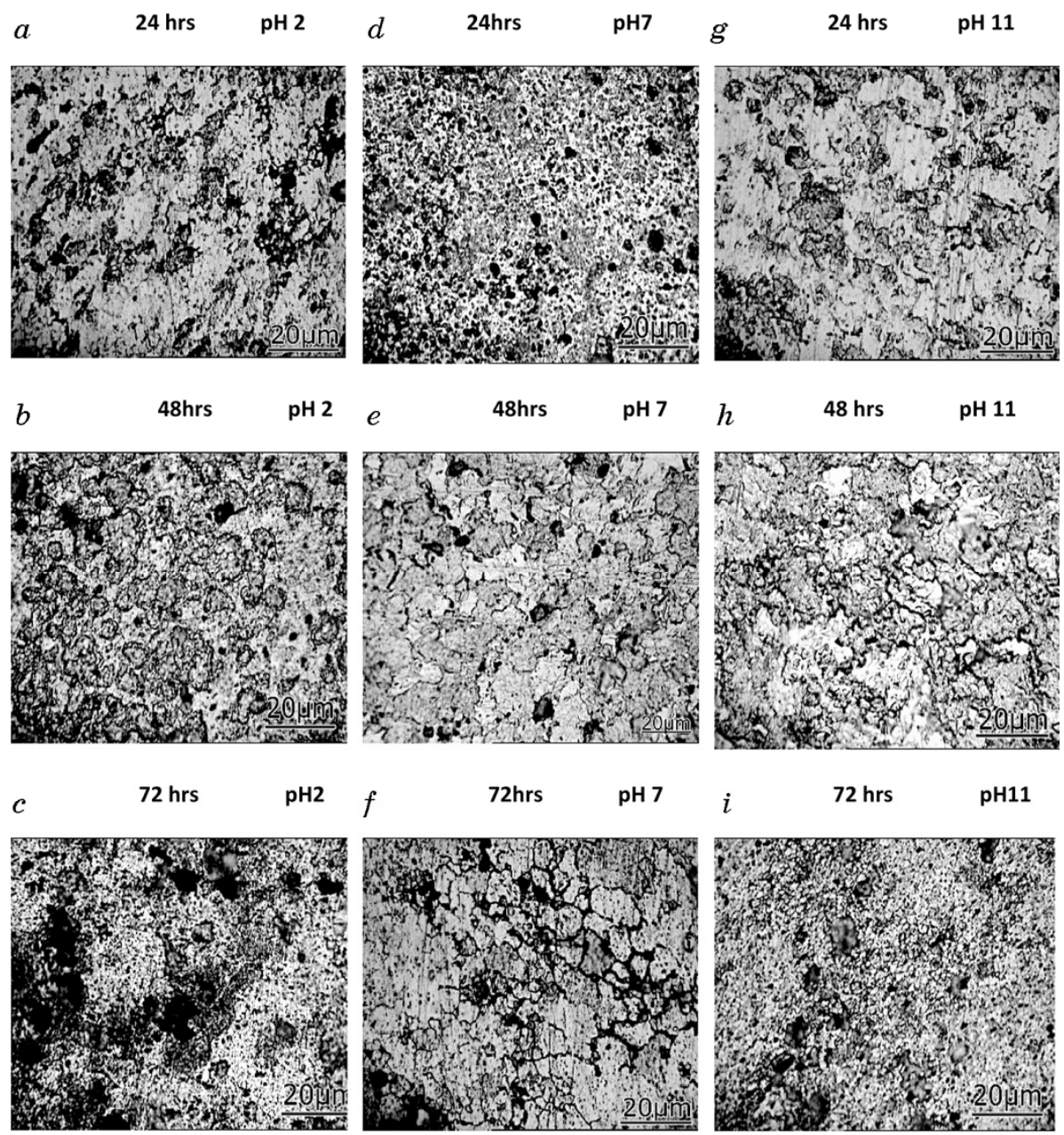

Fig. 5. Optical micrograph of the nugget at $\mathrm{pH} 2(a, b, c), \mathrm{pH} 7(d, e, f)$ and $\mathrm{pH}$ $11(g, h, i)$ and corresponding spraying time $(24,48$ and $72 \mathrm{hrs})$.

Figure 7 shows the micrographs of the HAZ region of the weld. It can be clearly seen that the corrosion attack on the weld is predominant in the HAZ and various researchers [26, 27] have reported the same.

Figure 3 shows the TEM image of HAZ. It can be seen that the structural form of the precipitates in $\mathrm{HAZ}$ is the same as that of the base material.

If $\mathrm{Al}-\mathrm{Cu}$ alloys are aged above $190^{\circ} \mathrm{C}$, the equilibrium $\mathrm{CuAl}_{2}$ intermetallic compound $(\theta)$ is formed and the alloy is severely overaged and weaker than the base material [38]. With temperatures in the range of 150 to $250^{\circ} \mathrm{C}$ in the $\mathrm{HAZ}$ region of the welded plates, the coarsening of precipitates in turn forms precipitated free zones. 

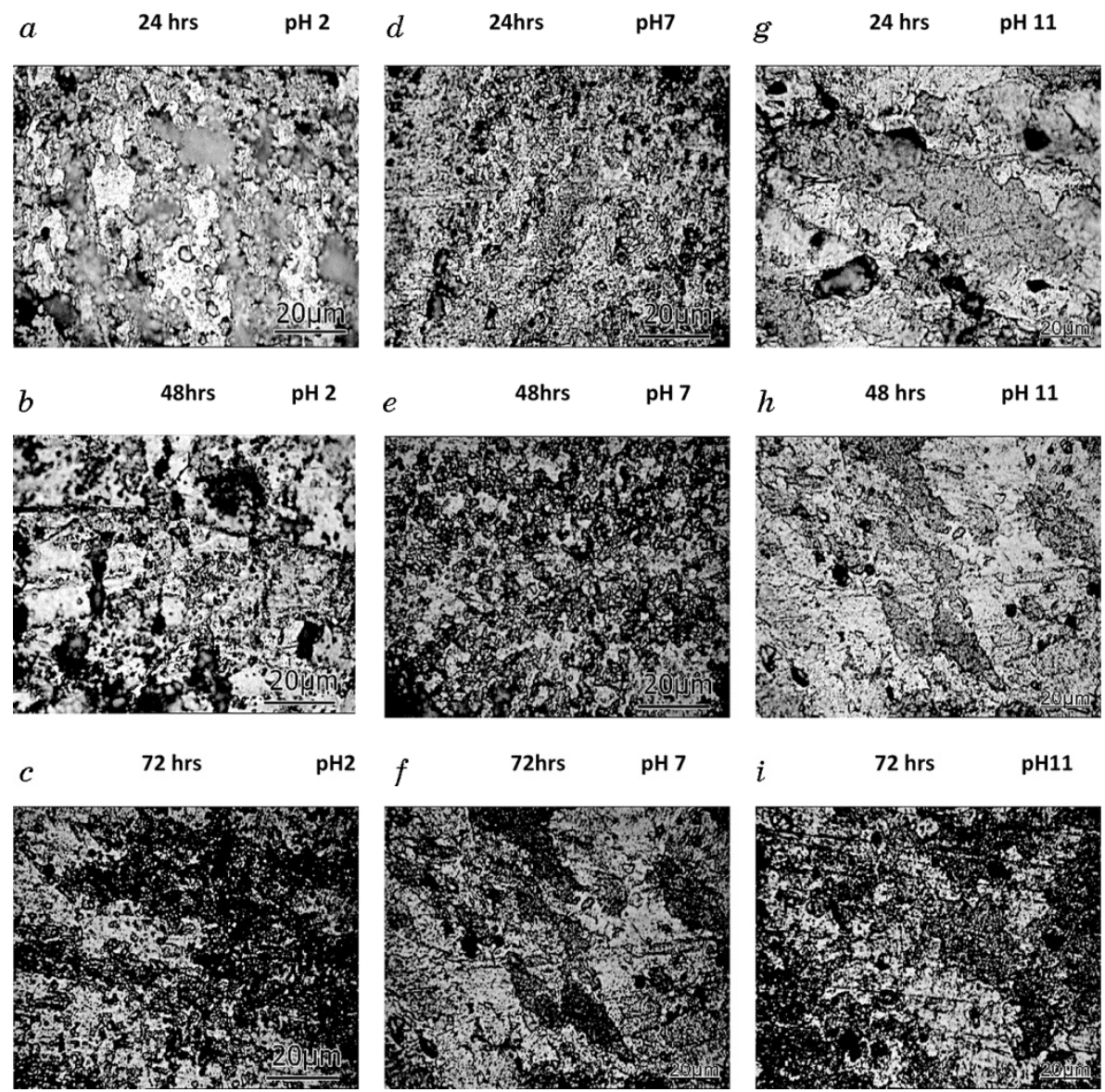

Fig. 6. Optical micrograph of the thermomechanically affected zone at $\mathrm{pH} 2$ $(a, b, c), \mathrm{pH} 7(d, e, f)$ and $\mathrm{pH} 11(g, h, i)$ and corresponding spraying time (24, 48 and $72 \mathrm{hrs})$.

These zones are obviously regions of weakness. It indicates that the precipitation of noble second phase particles $\left(\mathrm{CuAl}_{2}\right)$ at the grain boundaries causes depletion of copper near the grain boundaries, making these regions anodic with respect to the grain centre [41].

\section{CONCLUSIONS}

1. AA2219-T87 aluminium alloy $8.1 \mathrm{~mm}$ thick plates were successfully joined using friction stir welding.

2. The corrosion behaviour of the base material and friction stir welded joints was investigated using salt fog test (ASTM B117) at different $\mathrm{pH}$ values and spraying times. 

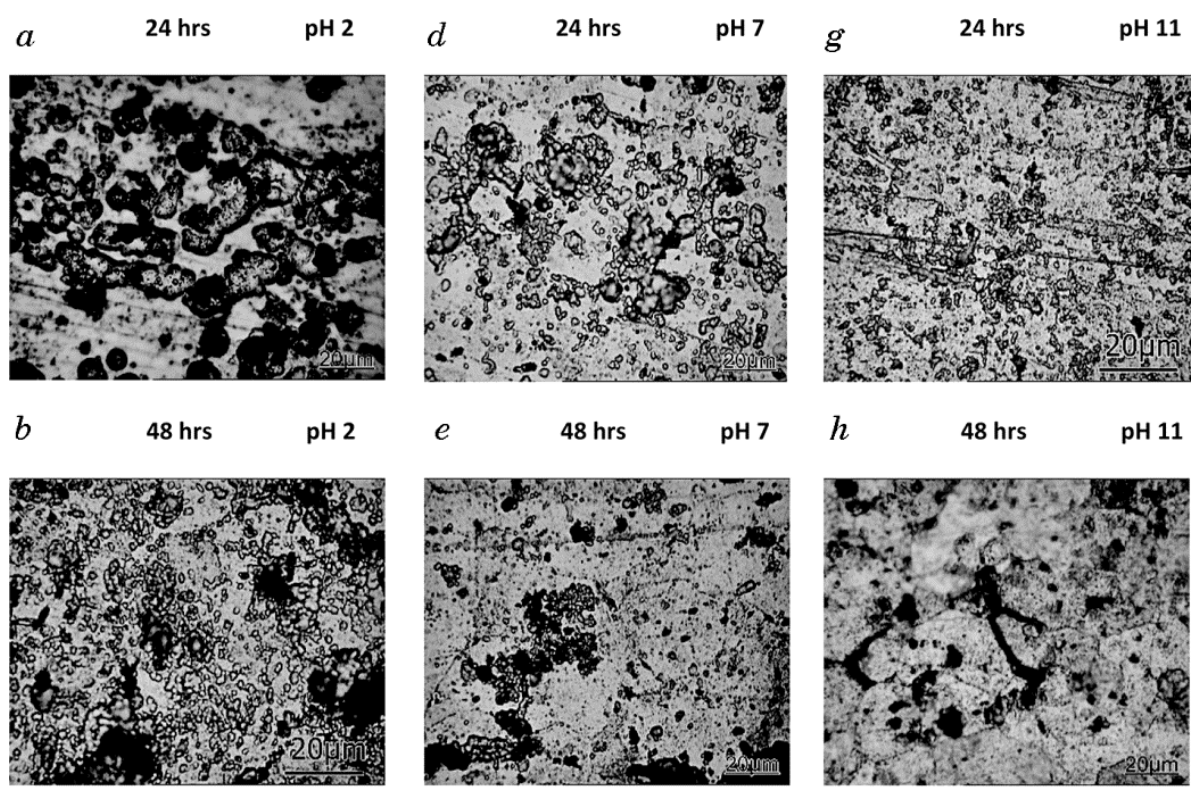

$h \quad 48 \mathrm{hrs} \quad \mathrm{pH} 11$

$c$

$72 \mathrm{hrs}$

pH 2
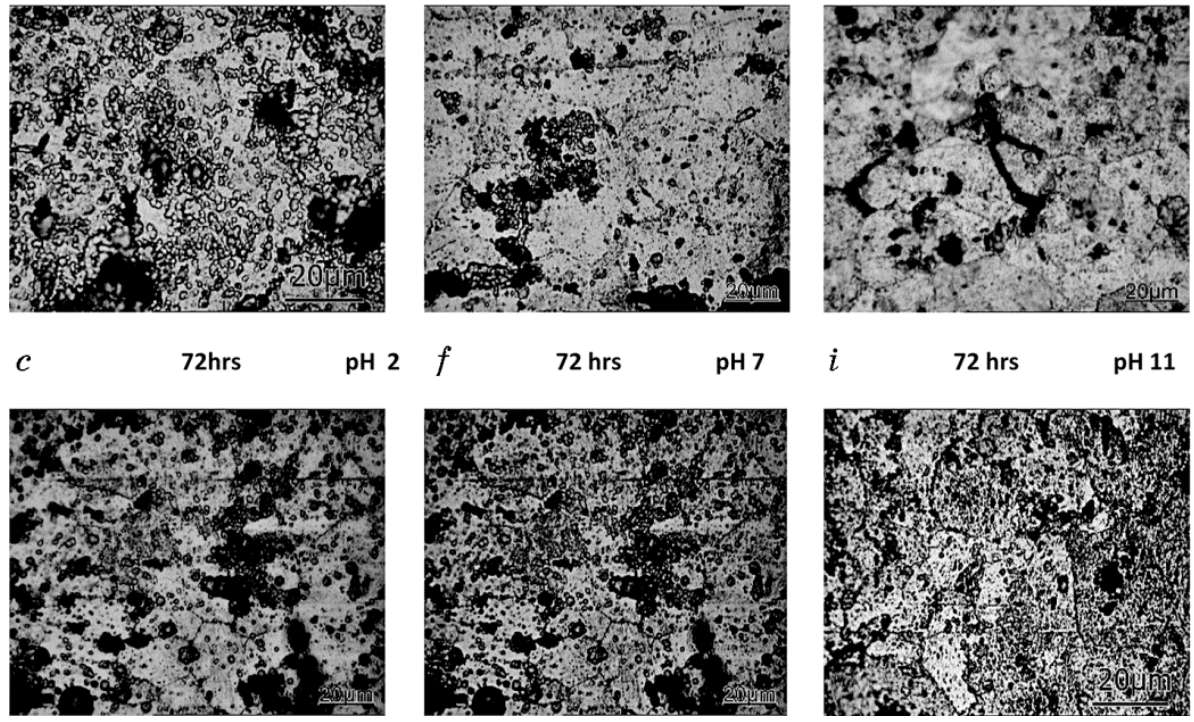

Fig. 7. Optical micrograph of the heat affected zone at $\mathrm{pH} 2(a, b, c), \mathrm{pH} 7$ ( $d$, $e, f)$ and $\mathrm{pH} 11(g, h, i)$ and corresponding spraying time $(24,48$ and $72 \mathrm{hrs})$.

3. It was observed that the welds exhibited excellent corrosion resistance in basic and neutral solution and not in acidic solution.

4. It was found that the corrosion rate decreases with increase in time of exposure at all $\mathrm{pH}$ values.

5 . It has been observed that the corrosion rate was predominant in acidic solution for the first $24 \mathrm{hrs}$ of spraying time.

6. It was found that corrosion attack is higher in the base material than in the weld metal at all $\mathrm{pH}$ values and spraying times. Within the weld, the heat-affected zone has been found to be more susceptible to corrosion, which is caused by the precipitation of the second phase particles $\left(\mathrm{CuAl}_{2}\right)$ at the grain boundaries, which causes depletion of copper near the grain boundaries, making these regions anodic in regard to the grain centre. 


\section{ACKNOWLEDGEMENT}

The authors are grateful to Dr. G. Madhusudhan Reddy, Scientist G, of Defence Metallurgical Research Laboratory (DMRL), Hyderabad for providing FSW facility to carry out this investigation.

\section{REFERENCES}

1. W. M. Thomas, E. D. Nicholas, M. G. Murch, P. Tempelsmith, and C. J. Dawes, GB Patent Application No. 9125978.8 (December 1991) (TWI Bull.: 1995), p. 124.

2. K. A. A. Hassan, P. B. Prangnell, A. F. Norman, D. A. Price, and S. W. Williams, Sci. Technol. Weld.JOI, 8: 257 (2003); DOI:10.1179/136217103225005480.

3. J. Q. Su, T. W. Nelson, R. Mishra, and M. Mahoney, Acta Mater., 51: 713 (2003); DOI:10.1016/S1359-6454(02)00449-4.

4. C. G. Rhodes, M. W. Mahoney, W. H. Bingel, R. A. Spurling, and C. C. Bampton, Scr. Mater., 36: 69 (1997); DOI:10.1016/S13596462(96)00344-2.

5. K. V. Jata, K. K. Sankaran, and J. J. Ruschau, Metall. Mater. Trans. A, 31A: 2181 (2000); DOI:10.1007/s11661-000-0136-9.

6. G. Liu, L. E. Murr, C. S. Niou, J. C. McClure, and F. R. Vega, Scr. Mater., 37: 355 (1997); DOI:10.1016/S1359-6462(97)00062-6.

7. Y.S. Sato, H. Kokawa, M. Enomoto, S. Jogan, and T. Hashimoto, Metall. Mater. Trans. A, 30A: 3125 (1999); DOI:10.1007/s11661-999-0223-5.

8. Y.S. Sato, H. Kokawa, M. Enomoto, and S. Jogan, Metall. Mater. Trans. A, 30A: 2429 (1999); DOI:10.1007/s11661-999-0251-1.

9. K. V. Jata and S. L. Semiatin, Scr. Mater., 43: 743 (2000); DOI:10.1016/S1359-6462(00)00480-2.

10. S. Benavides, Y. Li, L. E. Murr, D. Brown, and J. C. McClure, Scr. Mater., 41: 809 (1999); DOI:10.1016/S1359-6462(99)00226-2.

11. M. W. Mahoney, C. G. Rhodes, J. G. Flintoff, R. A. Spurling, and W. H. Bingel, Metall. Mater. Trans. A, 29A: 1955 (1998); DOI:10.1007/s11661-998-0021-5.

12. M. Peel, A. Steuwer, M. Preuss, and P. J. Withers, Acta Mater., 51: 4791 (2003); DOI:10.1016/S1359-6454(03)00319-7.

13. A. P. Reynolds, W. D. Lockwood, and T. U. Seidel, Mater. Sci. Forum, 331-337: 1719 (2000).

14. H. J. Liu, H. Fujii, M. Maeda, and K. Nogi, J.Mater. Process. Technol., 142: 692 (2003); DOI:10.1016/S0924-0136(03)00660-5.

15. B. Yang, J. Yan, M. A. Sutton, and A. P. Reynolds, Mater. Sci.Eng. A, 364: 55 (2004); DOI: 10.1016/S0921-5093(03)00532-X.

16. K. A. A. Hassan, A. F. Norman, and P. B. Prangnell, Mater. Sci. Forum, 396-402: 1549 (2002).

17. K. A. A. Hassan, A. F. Norman, and P. B. Prangnell, $3^{d}$ International Symposium on Friction Stir Welding (September 27-28, 2001, Kobe, Japan).

18. K. V. Jata, Mater. Sci. Forum, 331-337: 1701 (2000).

19. K. A. A. Hassan, A. F. Norman, D. A. Price, and P. B. Prangnell, Acta Mater., 
51: 1923 (2003); DOI:10.1016/S1359-6454 (02)00598-0.

20. J. D. Robson, A. Sullivan, H. R. Shercliff, and G. McShane, $5^{\text {th }}$ International Friction Stir Welding Symposium (September 14-16, 2004, Metz, France).

21. J. B. Lumsden, M. W. Mahoney, G. Pollock, and C. G. Rhodes, Corrosion, 55, No. 12: 1127 (1999); DOI:10.5006/1.3283950.

22. Y. Li, L. E. Murr, and J. C. McClure, Mater. Sci.Eng. A, 271: 213 (1999); DOI:10.1016/S0921-5093(99)00204-X.

23. F. Hannour, A. Davenport, and M. Strangwood, $2^{\text {nd }}$ International Symposium on Friction Stir Welding (June 26-28, 2000, Gothenburg, Sweden).

24. R. Ambat, M. Jariyaboon, A. J. Davenport, S. W. Williams, D. Price, and A. Wescott, $15^{\text {th }}$ International Corrosion Congress (September 22-29, 2002, Granada, Spain).

25. J. B. Lumsden, M. W. Mahoney, C. G. Rhodes, and G. A. Pollock, Corrosion, 59: 212 (2003); DOI:10.5006/1.3277553.

26. J. B. Lumsden, M. W. Mahoney, G. Pollock, and C. G. Rhodes, Corrosion, 55: 1127 (1999); DOI:10.5006/1.3283950.

27. C. S. Paglia, M. C. Carroll, B. C. Pitts, A. P. Reynolds, and R. G. Buchheit, Mater. Sci. Forum, 396-402: 1677 (2002).

28. W. Hu and E. I. Meletis, Mater. Sci. Forum, 331-337: 1683 (2000).

29. G. S. Frankel and Z. Xia, Corrosion, 55: 139 (1999);. DOI:10.5006/1.3283974.

30. J. Corral, E. A. Trillo, Y. Li, and L. E. Murr, J. Mater. Sci. Lett., 19: 2117 (2000); DOI:10.1023/A:1026710422951.

31. F. Zucchi, G. Trabanelli, and V. Grassi, Mater. Corros., 52: 853 (2001); DOI:10.1002/1521-4176(200111)52:11<853: AIDMACO853> 3.0.CO;2-1.

32. G. Biallas, R. Braun, C. D. Donne, G. Staniek, and W. A. Kaysser, $1^{\text {st }}$ International Symposium on Friction Stir Welding (June 14-16, 1999, Thousand Oaks, CA, USA).

33. A. Squillace, A. D. Fenzo, G. Giorleo, and F. Bellucci, J. Mater. Process. Technol., 152: 97 (2004); DOI:10.1016/j.jmatprotec.2004.03.022.

34. S. Williams, R. Ambat, D. Price, M. Jariyaboon, A. Davenport, and A. Wescott, Mater. Sci. Forum, 426-432: 2855 (2003).

35. B. J. Connolly, A. J. Davenport, M. Jariyaboon, C. Padovani, R. Ambat, S. W. Williams, D. A. Price, A. Wescott, C. J. Goodfellow, and C. M. Lee, $5^{\text {th }}$ International Friction Stir Welding Symposium (September 14-16, 2004, Metz, France).

36. Standard Practice for Operating Salt Spray Apparatus (ASTM B117, American Society for Testing of Materials: 2003).

37. C. S. Paglia and R. G. Buchheit, Mater. Sci. Eng. A, 492: 250 (2008).

38. K. S. Arora, S. Pandey, M. Schaper, and R. Kumar, J. Mater. Sci. Technol., 26, No. 8: 747 (2010).

39. K. A. A.Hassan, P. B. Prangnell, A. F. Norman, D. A. Price, and S. W. Williums, Sci. Technol. Welding and Joining, 8, No. 4: 257 (2003).

40. Y. Sato, H. Kokawa, M. Enomoto, and S. Jogan, Metall. Mater. Trans. A, 30: 2429 (1999).

41. K. Surekha, B. S. Murty, and K. Prasada Rao, Solid State Sci., 11: 907 (2009). 